DOI https://doi.org/10.32837/app.v0i65.305

УДК 316.774:291.13

О. В. Максимчук

ORCID ID: https://orcid.org/0000-0003-3063-0161

викладач кафедри фрілософії та суспільних дисииплін

Уманського державного педагогічного університету імені Павла Тичини

С. С. Бондар

ORCID ID: https://orcid.org/0000-0002-8231-5166

кандидат політичних наук,

доиент кафедри філософії та суспільних дисциилін

Уманського державного педагогічного університету імені Павла Тичини

\title{
РОЛЬ МАС-МЕДІА У ФОРМУВАННІ ПОЛІТИЧНИХ МІФІВ
}

Постановка проблеми. Трансформація та динаміка змін соціального середовища породжують низку актуальних проблем XXI ст. До них можемо зарахувати і таке явище, як міфологізація політики. Цю проблему характеризують як наростаючу масовізацію політичних процесів, так і подальший динамічний розвиток інформаційних медіатехнологій. Масовізація політики була результатом зростання глобальної невизначеності, турбулентності та суперечливого розвитку політичних процесів в усьому світі. Своєю чергою мас-медіа у зростаючій міжнародній та геополітичній конкуренції використовуються владою як потужний інструмент політичного впливу, при цьому виконуючи не лише інформаційну, а й ідеологічну функцію. Поєднання цих двох фундаментальних процесів призводить до загальної ірраціоналізації політики та створює надзвичайно сприятливі умови для контролю над політичною свідомістю та поведінкою мас за допомогою технологій політичного міфотворення.

Ці явища та процеси є досить характерними для нашої країни, оскільки все існування із часу здобуття незалежності для України позначене різким політичним протистоянням в умовах кризи, яка створила сприятливі умови для створення й поширення політичних міфів. Як показує політична практика, діалог між владою та суспільством будується саме на міфологічних підставах.

Однак питання щодо природи, сутності, функцій, місця та ролі засобів масової інформації у міфотворчості політичного процесу досі залишаються дискусійними, що знайшло відображення в різних, часом діаметрально протилежних точках зору та концепціях. Тому міфологія стає потужною науковою сферою, в якій беруть участь представники різних сфер гуманітарних знань. У цій взаємодії політологи вивчають феномен політичного міфу та технологію створення політичного міфу.

Мета. Метою нашої статті є здійснення комплексного аналізу особливостей творення засобами масової інформації сучасних політичних міфів. Відповідно до теми та мети основні завдання полягають у тому, щоб визначити особливості політичного міфу як чинника трансформації політичної свідомості та розглянути механізми політичного міфотворення сучасними засобами масової інформації.

Аналіз останніх досліджень та публікацій. У процесі написання статті було використано та проаналізовано низку грунтовних наукових досліджень, статей у періодичних виданнях, бібліографічних показників тощо. Серед ключових дослідників, чиї праці було розглянуто, варто виділити Г. Вонсович, Ю. Гайдук, О. Гойман, Е. Данилова, А. Дємідова, Л. Зубрицька. Проблемами політичного впливу та питаннями політичного маніпулювання займались, у тому числі, вітчизняні науковці. Окремі аспекти міфотворчості знайшли висвітлення в роботах М. Еліаде, Т. Рассадіної, С. Лебедєва, О. Макарової, Д. Усова, П. Гуревича, Е. Кассірера, К. Хюбнера, О. Донченко, Ю. Романенко, Р. Барта, Д. Дадаяна, О. Заздравнової, Ю. Левенця, Г. Почецова, Т. Паніотової, С. Кара-Мурзи, Т.Ю. Шайгородського та інших. Дослідження цих авторів присвячені вивченню проблеми політичного міфу та архетипів, що лежать в основі будь-яких міфів. 
У публічній сфері за допомогою мас-медіа відбуваються трансформаційні зміни, в основі яких - зміна природи політики. Ці зміни відбуваються завдяки включенню до публічної дискусії багатьох сфер людської діяльності, в тому числі макро- та мікроекономічних процесів, що тривалий час мали обмеження у вигляді латентного внутрішнього життя домашнього господарства (Анохін, 2016, с. 44-56), тобто ринком і родиною. Таким чином, політика, що функціонує в рамках суспільства, стає невід'ємною частиною життя кожного громадянина. Предметом політичної дискусії може бути будь-яка тема, висвітлена у 3МI, яка може вплинути на виборчу поведінку громадян (Вонсович, 2).

Міф є універсальною константою та функціонує в різних площинах соціального життя. Він створює такі умови для інтеграції різних груп, незважаючи на процеси, що виконується без участі єднання людей та раціональної свідомості. У такий спосіб формується специфічний зв'язок із зовнішньою дійсністю. При цьому суспільство об'єднується групою панівних форм мислення та системою міфів, що підтримують та зумовлюють активність його членів (Гойман, 2013, с. 44).

Також можемо говорити про те, що міф належить та входить до політичної дійсності, при цьому людина відчуває ідентичність, та робить можливим відчуття духу спільноти (Данилов, 2008 с. 27). Таким чином, встановлюються суспільні цінності і соціальна ієрархія, а також стає правомірною та законодавчою структура влади. Сучасна політична дійсність, беручи участь у політичній дискусії, для якої характерною властивістю є різнополярність досліджуваних тем, проблем, де головну роль виконують мас-медіа, також має політичні міфи.

Спільні площини функціонування міфу, політики та засобів масової інформації в сучасному світі зводяться до того, що мас-медіа творять нову якість комунікації в суспільстві, являють собою безпосередній вплив на кондицію політичного міфу сьогодення. Також в умовах сьогодення за допомогою спільного функціонування міфи та засоби масової інформації стають взаємозалежними. При цьому навіть із погляду, що мас-медіа мають позитивне значення, оскільки вони є ефективним елементом соціальної взаємодії та підтримують суспільну рівновагу, маніпулятивні можливості ЗМІ безмежні. Щодня сучасний світ стає дедалі більш інформаційно насиченим, а тому часто незрозумілим для людей. Людина не здатна самостійно отримати й перевірити всю необхідну їй інформацію, а тому змушена багато що сприймати як правду. Внаслідок цього мас-медіа надають суспільству не лише знання про навколишню дійсність, але й вагомо формують емоційні та поведінкові стереотипи.

Таким чином, сучасні політичні міфи є наслідком певної залежності. У сучасній гіпердійсності щораз більше явищ, які отримують політичний вимір. Сфери, які до цього часу мали небагато спільного з політикою, починають відігравати в політичному вимірі важливу роль. Поява в сучасному світі публічної сфери поряд із політичною і приватною призвела до корінних змін у способах спостереження за політикою. Преса, радіо, клуби за інтересами і неурядові організації, які є елементами публічної сфери, стали втручатись у політичний простір і провели реорганізацію його меж. Згадані інституції, довершуючи інтенсивний вплив на способи вирішення питань у державі, також змінили способи спостереження за політикою (Кассирер, с. 387-390).

Підкреслюючи роль міфу як слова, яке є комунікатором і посідає властивості письмової форми і форми зображення, Бартес акцентує, що слово, попри свій комунікаційний потенціал, дає змогу зберегтись міфічній мові, надаючи йй тим самим подібних властивостей комунікатора. Міфи разом із медіа також виконують педагогічну функцію. Здійснюючи в певний спосіб освіту суспільства, міфи спільно з медіа є суспільними скеровувачами. Інакше кажучи, вони впливають на суспільну і політичну поведінку. Наприклад, реклама, фотографія, фільм, репортаж, представлені в мас-медіа видовища вказують на певні схеми поведінки, роблять їх широковживаними в суспільстві (Кирилова, 2015, с. 80-93).

Засоби масової інформації (ЗМІ) - це публічне поширення різних даних і відомостей за допомогою різноманітних технічних засобів (телебачення, радіо, інтернет, газети, журнали). Варто зазначити, що стінгазети, бібліотеки, форуми, інтернет-блоги, конференції і подібне не належать до засобів масової інформації. Таким чином, у політичній, соціальній, економічній та інших сферах життя населення, 3MI, крім передачі даних, також є способом агітації, маніпуляції та пропаганди. 
До того ж «соціальна відповідальність має не менше значення, ніж розвинута економічна інфраструктура, політична стабільність або втілення в життя проектів інноваційного розвитку» (Гайдук, 2017).

Варто зазначити, що мас-медіа через навчання, інформування, переконання, навіювання та інші психологічні методи впливають на маси. Завдяки тиражуванню інформації стосовно духовних цінностей, соціальних вимог стандартизуються і стереотипізуються поведінкові й світоглядні норми суспільного життя (Гусєва).

Ми вже зазначали раніше, «ЗМІ мають справу з інформацією, і саме контроль за інформацією дає змогу маніпулювати масовою свідомістю, створювати в ній модель вигідної суб'єкту впливу дійсності та вирішувати, які проблеми нині є найбільш актуальними. Штучно відтворюється таке явище, як медіа-свідомість (тобто свідомість, заснована на хибних цінностях, маніпулятивних інтерпретаціях, подвійній моралі), коли реальність, пропонована ЗМІ, відрізняється від дійсної. Громадська думка через медіа-свідомість значно спотворюється та має значні відмінності з реальністю» (Гусєва).

За допомогою ЗМІ інформацію можна:

- спотворити за допомогою неповного, одностороннього викладу (тобто фрагментарний спосіб поширення інформації - частка інформації подрібнюється на менші частки та коли інформація подається єдиним неопрацьованим потоком, що не дає людині змогу сформувати цілісну картину подій);

- показати щось у тому вигляді, в якому вигідно для когось;

- звертаючи увагу на окремі аспекти події, приховати малозначну деталь, замовчуючи інші, що створює додаткову змогу маніпулювати свідомістю людей;

- створити «інформаційний галас», коли зниження сприйняття фактів досягається шляхом подачі такої кількості новин, за якої стає неможливим їх сортування;

- відволікти увагу від дійсно важливих подій шляхом надання яскравої, але несуттєвої інформації;

- оперативно подати навіть неперевірену інформацію, адже будь-яке перше повідомлення про подію справляє значно сильніший вплив на аудиторію, ніж наступні;

- поширювати певний погляд на інформацію як їі єдино можливий та правильний варіант.

На цьому етапі розвитку незалежної України виникає своєрідна культурна дискусія, що полягає у протиставленні реалій та міфів. На противагу раціональним аргументам пропонується тенденція свідомості, яка створює форми мислення в міфологізованому вигляді. Виникає вона як свого роду захисна реакція. У радянські часи сукупність знань та поглядів поставала перед нами у вигляді ієрархічного цілого. Нині внаслідок шалених темпів накопичення знань світогляд пересічної людини розсипався на мозаїку випадкових, погано пов' язаних між собою понять. Такий мозаїчний тип свідомості сприяє нав' язуванню потрібних поглядів і переконань через рекламу, тому що знання формуються значною мірою 3МI, а не системою освіти. Іншими словами, створення політичного міфу відбувається за допомогою засобів політичного маніпулювання та політичної реклами.

Таким чином, політична реклама - це специфічна система прийомів масової комунікації. При цьому політичне міфотворення стає неодмінною ознакою сучасності. Воно не пояснює реальної дійсності, а використовує її для створення ілюзії, гармонійної конструкції, своєрідної системи координат свідомості, специфічного відтворення суспільних явищ На думку сучасних дослідників, політичний міф має відштовхуватись від національних особливостей менталітету, тобто національних архетипів, які породжуються історією, долею народу, його культурою.

У рамках політологічної науки виділяється та аналізується ментальність (менталітет) на основі моделі соціальної структури суспільства або типології суб'єктів політики, тобто менталітет розглядається як психологія (іноді характер), свідомість і самосвідомість якоїсь соціальної групи, представників певної соціально-політичної спільності людей. Іншими словами, формування менталітету відбувається під впливом соціокультурних факторів, традицій, культури, соціальних та державних інститутів суспільства. Підсумовуючи, можна говорити, що політичний менталітет - це специфічна структура та сукупність різних психічних властивостей, якостей, особливостей та проявів, що використовуються для позначення оригінального способу мислення. 
Нинішній розвиток подій у політичній сфері в Україні показує реальну боротьбу та зіткнення різних міфів. До них в основному належать як ті, що утворюють основу політичної культури іï незалежного державного існування. Причиною деміфологізації є ті зміни політичної ситуації в Україні, які виявили недієздатність міфології, що вироблялася радянською політичною культурою і в межах ії претендувала на абсолютне значення. Ситуація тотальної деміфологізації свідомості зумовила потребу поновлення міфологічного потенціалу політичної культури. Анархічність міфів зумовлена також культурною неоднорідністю України. Міф дає відповіді на запитання, які неможливо пояснити формулами та раціональними доказами (Смирнова, 2016, с. 64).

Коли ми говоримо про 3МІ як про «четверту неформальну гілку влади», треба наголосити на процесах між 3МІ та формальними гілками влади. Таким чином, ми розглянули особливості творення сучасних політичних міфів засобами масової інформації і дійшли висновків: ідеологія є, з одного боку, механізмом втілення результатів розумової діяльності, певних теорій та концепцій у соціальну практику, а з іншого - полем політичної діяльності суб'єкта. Механізм дії сучасного політичного міфу розкривається через його структурні, функціональні та технологічні особливості. Сучасний політичний міф має синтетичний характер.

$€$ універсальний алгоритм формування політичного міфу засобами масової інформації. Міф фіксується у свідомості через певні ритуали, які $є$ колективними діями сильної емоційної взаємодії та розуміння, зміцнюють колективну єдність і $є$ важливим фактором політичного регулювання та встановлення певної моделі суспільно-політичної системи. Зрештою, міф впроваджується у свідомість мас за допомогою засобів масової інформації та інших установ масової культури, для цього використовується низка методологічних прийомів та прийомів (включаючи вигадку фактів, штучний відбір подій реальності для спілкування, використання маніпулятивної семантики, спрощення та стереотипізації, фрагментації та терміновості, сенсаційності, «інформаційного шуму»).

Загалом можемо підсумувати, що нині засоби масової інформації стали потужним інструментом формування політичних міфів та впливу на політичну свідомість, цим самим завдавши величезного удару по інформаційній безпеці сучасного суспільства.

\section{Лimepamypa:}

Анохін М.Г. Політична система: перехідні процеси. Москва : Інфомарт, 2016. 301 с.

Вонсович Г.Б. Політичний міф як чинник трансформації політичної свідомості. URL: http://geojournal.igs-nas.org.ua/index.php/2227-6246/article/viewFile/162210/161173.

Гайдук Ю. Мас-медіа як творці сучасних політичних міфів / Ю. Гайдук, В. Зінчук. Укр. наи. ідея: реалії та перспективи розъ. 2017. Вип. 19. С. 72-76.

Гойман О. Особливості сучасної політичної міфотворчості. Проблеми гуманітарних наук. Філософія. 2013. Вип. 31. С. 40-50.

Гусева С.А. Современный политический миф: игра по законам архаики. Свердловская региональная общественная организация «Центр психоанализа». URL: http:/ / freud.by.ru/pages/guseva.shtml.

Данилов А.Н. Журналистика в переходный период: проблемы и перспективы. Москва, 2008. 132 с.

Данилова Е.Е. Деятельность СМИ в условиях открытого, закрытого и переходного обществ: методологический анализ. URL:www.lib.ua-ru.net/diss/zakl/92502.

Дебор Г. Общество спектакля. Библиотека Гумер - гуманитарные науки. URL: http://www.gumer.info/ bibliotek_Buks/Polit/Debor/index.php.

Дємідова А.А., Ярова А.Б. Засоби масової інформації як «четверта неформальна гілка публічної влади»: способи медіа-маніпуляції. Електронний журнал «Державне управління: удосконалення та розвиток» включено до переліку наукових фахових видань України з питань державного управління». 2019. № 4. URL: http:// www.dy.nayka.com.ua/pdf/4_2018/102.pdf.

Зубрицька Л.Й. Міф як феномен сучасної політики : автореф. дис. ... канд. політ. наук : 23.00 .01 «Теорія та історія політичної науки». Київ : Київський національний ун-т ім. Тараса Шевченка, 2005. 14 с.

Кассирер Э. Техника современных политических мифов. Библиотека «Полка букиниста». URL: http://society.polbu.ru/political_science/ch65_i.html.

Кириллова Н.Б. Мифотворчество в медиакультуре. Общественные науки и современность. 2015. № 5. С. 155-165. Кривцун К. Как СМИ нами манипулируют. Bad news: сайт. URL: http:/ / badnews.org.ru/news/kak_smi_ nami_manipulirujut/2010-04-20-713. 
Смирнова М. Створення стереотипів засобами масової інформації в добу інформаційного суспільства. Теле- та радіожурналістика. 2016. Вип. 15. С. 63-67. URL: http://nbuv.gov.ua/UJRN/Tir_2016.

\section{References}

Anokhin M.H. (2016). Politychna systema: perekhidni protsesy. M.: Infomart, 301 s.

Vonsovych H.B. Politychnyi mif yak chynnyk transformatsii politychnoi svidomosti. URL: http://geojournal.igs-nas.org.ua/index.php/2227-6246/article/viewFile/162210/161173

Haiduk Yu. (2017) Mas-media yak tvortsi suchasnykh politychnykh mifiv / Yu. Haiduk, V. Zinchuk. Ukr. nats. ideia: realii ta perspektyvy rozv. Vyp. 19. S. 72-76.

Hoiman O. (2013). Osoblyvosti suchasnoi politychnoi mifotvorchosti. Problemy humanitarnykh nauk. Filosofiia. Vyp. 31. S. 40-50.

Huseva S.A. Sovremennyi polytycheskyi myf: yhra po zakonam arkhayky. Sverdlovskaia rehyonalnaia obshchestvennaia orhanyzatsyia «Tsentr psykhoanalyza»: [sait]. URL: http://freud.by.ru/pages/guseva.shtml. Danylov A.N. (2008). Zhurnalystyka v perekhodnyi peryod: problemi y perspektyvi. M. $132 \mathrm{~s}$.

Danylova E.E. Deiatelnost SMY v uslovyiakh otkrytoho, zakrytoho y perekhodnoho obshchestv: metodolohycheskyi analyz. URL: www.lib.ua-ru.net/diss/zakl/92502.

Debor H. Obshchestvo spektaklia. Byblyoteka Humer - humanytarnye nauky. URL: http://www.gumer.info/ bibliotek_Buks/Polit/Debor/index.php.

Diemidova A.A., Yarova A.B. (2019). Zasoby masovoi informatsii yak «chetverta neformalna hilka publichnoi vlady»: sposoby media-manipuliatsii. Elektronnyi zhurnal «Derzhavne upravlinnia: udoskonalennia ta rozvytok» vkliucheno do pereliku naukovykh fakhovykh vydan Ukrainy z pytan derzhavnoho upravlinnia. № 4. URL: http:/ / www.dy.nayka.com.ua/pdf/4_2018/102.pdf.

Zubrytska L.Y. (2005). Mif yak fenomen suchasnoi polityky: avtoref. dys. kandydata politychnykh nauk. 23.00.01 - teoriia ta istoriia politychnoi nauky. K. Kyivskyi natsionalnyi un-t im. Tarasa Shevchenka, $14 \mathrm{~s}$.

Kassyrer E. Tekhnyka sovremennykh polytycheskykh myfov. Byblyoteka «Polka bukynysta». URL: http:// society.polbu.ru/political_science/ch65_i.html.

Kyryllova N.B. (2015) Myfotvorchestvo v medyakulture. Obshchestvennye nauky y sovremennost. № 5. S. $155-165$.

Kryvtsun K. Kak SMY namy manypulyruiut. Bad news: [sait]. URL: http://badnews.org.ru/news/kak_smi_ nami_manipulirujut/2010-04-20-713.

Smyrnova M. (2016). Stvorennia stereotypiv zasobamy masovoi informatsii v dobu informatsiinoho suspilstva. Tele- ta radiozhurnalistyka. Vyp. 15. S. 63-67. URL: http:/ / nbuv.gov.ua/UJRN/Tir_2016.

\section{Анотація}

Максимчук О. В., Бондар С. С. Роль мас-медіа у формуванні політичних міфів. - Стаття.

У статті досліджено роль мас-медіа у становленні та формуванні сучасних політичних міфів. Зазначено, що інформаційні засоби масової інформації своєю чергою в умовах загальної нестабільності та зростаючої міжнародної та геополітичної конкуренції використовуються владою як потужний інструмент політичного впливу i, таким чином, виконують не інформаційну, а ідеологічну функцію. Поєднання цих двох фундаментальних процесів призводить до загальної ірраціоналізації політики та створює надзвичайно сприятливі умови для контролю над політичною свідомістю та поведінкою мас за допомогою технологій політичного міфотворення. Розкрито сутність співвідношення категорії міфу і засобів масової інформації в соціально-політичній площині. Акцентовано на особливостях творення сучасних політичних міфів шляхом тотальної експансії мас-медіа у сферу не лише суспільної свідомості, але й способу сучасного буття соціумів загалом і владних відносин зокрема. Міф поєднує раціональне і ірраціональне знання, він є характерною рисою історичної пам'яті народу і сучасних оцінок природного і соціального світу. Зазначено, що політична реклама є специфічною системою прийомів масової комунікації. Політичне міфотворення стало неодмінною ознакою сучасності, політичній міфології більше притаманна «спонтанність» розвитку, незалежність від волі осіб та інститутів, причетних до їі створення. Це зумовлено тим, що політична міфологія формується в процесі взаємодії ідеологічної доктрини з наявними стереотипами суспільної свідомості. Визначено, що процес трансформації публічної сфери супроводжується зміною природи політики за допомогою засобів масової інформації. Відбувається це за допомогою включення до публічної дискусії багатьох сфер людської діяльності. Узагальнено, що 3МІ через повідомлення, інформування, навчання, переконання, навіювання та інші психологічні методи впливають на маси. Зазначено, що політичний міф став складником добре відпрацьованої технології маніпулювання - і не лише «побутовою» частиною масової свідомості, але й теоретичною (ідеологічною) ï складовою частиною. Політичний міф використовується як інструмент для конструювання політичної реальності, побудови нової ціннісної системи. Зроблено 
висновок, що нині мас-медіа стали потужним інструментом формування політичних міфів та впливу на політичну свідомість, цим самим завдавши величезного удару по інформаційній безпеці сучасного суспільства. Зазначено, що ознакою є характерний для міфологічної свідомості та культури загалом провінціалізм, що поряд 3 агресією та анархією міфів утворює визначальну рису нинішньої ситуації. Деякі події та явища сучасної політичної дійсності, що здаються, на перший погляд, нелогічними та неможливими для пояснення, можуть стати зрозумілішими, якщо розглядати їх із точки зору іншої, міфологічної логіки, що домінує в масовій, у тому числі масовій політичній, свідомості.

Ключові слова: політичний міф, плив, інформація, мас-медіа, формування.

\section{Summary}

Maksymchuk O. V., Bondar S. S. The role of the media in the formation of political myths. - Article.

The article examines the role of mass media in the formation and formation of modern political myths. It is noted that the media, in turn, in the context of general instability and growing international and geopolitical competition, are used by the authorities as a powerful tool of political influence and thus perform not an informational but an ideological function. The combination of these two fundamental processes leads to a general irrationalization of politics and creates extremely favorable conditions for the control of political consciousness and behavior by the masses of political myth-making. The essence of a parity an a category of a myth and mass media in a sociopolitical plane is opened. It is accented on features of creation of modern political myths by total expansion of mass-media to sphere not only public consciousness, but also a way of modern life of societies in general, relations of power in particular. Myth combines rational and irrational knowledge, it is a characteristic feature of the historical memory of the people and modern assessments of the natural and social world. It is noted that the political myth has become a component of a well-established technology of manipulation - and not only a "domestic" part of the mass consciousness, but also a theoretical (ideological) component. Political myth is used as a tool for constructing political reality, building a new value system. It is generalized that the media influence the masses through messages, information, training, persuasion, suggestion and other psychological methods. It is stated that political mythology is more inherent in the "spontaneity" of development, independence from the will of individuals and institutions involved in its creation. This is due to the fact that political mythology is formed in the process of interaction of ideological doctrine with the existing stereotypes of public consciousness. Ultimately, both ideology and mythology are important elements of the symbolic world of politics, both of which aim to form a value and ideological paradigm. It has been determined that the process of transformation of the public sphere is accompanied by a change in the nature of politics through the media. This happens through the inclusion of many spheres of human activity in public discussion. It is concluded that today the mass media have become a powerful tool for forming political myths and influencing the political consciousness, thus dealing a huge blow to the information security of modern society.

Key words: political myth, flow, information, mass media, formation. 